DOMINIK SZULC - LUBLIN

\title{
MUZEUM KLASZTORU OJCÓW DOMINIKANÓW W JANOWIE LUBELSKIM - NOWA PLACÓWKA MUZEALNA KOŚCIOLA KATOLICKIEGO W POLSCE
}

Janów Lubelski, miasto lokowane na gruntach wsi Biała w 1640 r., bardzo szybko doczekało się przybycia zakonników dominikańskich. Pozytywnie świadczyło to o mieście, gdyż Dominikanie jako miejsca lokalizacji swoich zgromadzeń wybierali najczęściej miasta sprawnie funkcjonujące i dobrze rozwijające się. Najbliższym względem Janowa klasztorem był wówczas klasztor kanoników regularnych laterańskich w Kraśniku, sprowadzonych tamże jeszcze w latach 1468-1469, chociaż ich ściągniecie do sąsiednich Modliborzyc planował rzekomo w latach 30 lub 40-tych XVII w. właściciel tego miasta Stanisław Wieteski. W Janowie inicjatywa fundacji klasztoru miała wyjść od Ordynatowej Katarzyny Zamoyskiej z Ostrogskich, zaś przekazanie tej fundacji Dominikanom miało miasto i zakon zawdzięczać wpływom ojca Franciszka Grabieckiego, dominikanina, ówczesnego spowiednika Zamoyskich. Klasztor dla janowskiego zgromadzenia wzniósł Ordynat Jan Zamoyski w latach 1659-1660, w miejscu w którym poprzednio istniała drewniana kaplica pochodząca z lat 1647-1648, a mająca upamiętnić miejsce objawień maryjnych sprzed 2 lat. Erekcji klasztoru janowskiego dokonał bp. krakowski Andrzej Trzebicki 30 lipca 1659 r., zaś pierwotnym uposażeniem ziemskim nowego konwentu stało się kilka pobliskich wsi, co potwierdził w 1676 r. król Jan III Sobieski. Dominikanie objęli klasztor w posiadanie 8 września 1660 r., jednak dopiero w 1665 r. usamodzielnił się on (poprzednio był wikariatem), a pierwszym przeorem zgromadzenia został o. Dominik Ożarowski. Obecny kościół poklasztorny p.w. św. Jana Chrzciciela wzniesiono w stylu barokowym dopiero w latach 1694-1700 za pontyfikatu przeora Jacka Chylickiego. Zgodę na to wyraził bp. Jan Siewierski, zaś kamień węgielny pod tę budowę położył sufragan krakowski Mikołaj Oborski. Konsekracji świątyni dokonał z kolei w 1742 r. sufragan Michał Kunicki, chociaż samą budowę zakończono dopiero w 1769 r. Kres konwentu janowskiego położył ukaz carski z 27 października 1864 r. kasujący w zaborze rosyjskim Zakon św. Dominika. Opuszczanie klasztoru w Janowie następowało od 15 do 27 listopada 1864 r., a zakonnicy udali się do klasz- 
toru w Klimontowie. Wśród nich był ostatni przeor Wawrzyniec Klimkiewicz, jednak jeszcze przez jakiś czas klasztor znajdował się pod zarządem innego Dominikanina o. Kornelego Mikusińskiego. Kres zgromadzenia janowskiego położyło ostatecznie przeniesienie ośrodka miejscowej parafii z kościoła w Białej do kościoła poklasztornego właśnie, co nastąpiło w grudniu $1867 \mathrm{r}$.

W dniu 15 września $2010 \mathrm{r}$. w dawnych zabudowaniach klasztornych dokonano oficjalnego otwarcia Muzeum klasztoru janowskiego. Poprzedziły go uroczystości 25. rocznicy Koronacji Cudownego Obrazu Matki Bożej Łaskawej odbyte na wewnętrznym dziedzińcu klasztoru oraz wieczór poezji maryjnej w wykonaniu m.in. aktorów scen warszawskich Alicji Jachiewicz i Stefana Szmidta. Na tę okazję przeniesiono na miejsce uroczystości uznany w 1762 r. za cudowny obraz Matki Bożej Łaskawej, namalowany być może w XVI w. Następnie grupa kilkudziesięciu uczestników uroczystości, a wśród nich nie tylko miejscowi duchowni i mieszkańcy, ale także władze Miasta i Powiatu w osobach Burmistrza Krzysztofa Kołtysia i Starosty Zenona Sydora, udała się do pomieszczeń przeznaczonych na Muzeum, gdzie dokonano poświęcenia ekspozycji i wysłuchano okolicznościowych przemówień w wykonaniu m.in. Dyrektor Muzeum Regionalnego w Janowie mgr Barbary Nazarewicz, ks. seniora inf. Edmunda Markiewicza i Dyrektora Muzeum Diecezjalnego w Sandomierzu ks. Andrzeja Rusaka.

Prace nad przygotowaniem Muzeum trwały już od niemal roku. Pomysłodawcą przedsięwzięcia był kustosz miejscowego Sanktuarium Matki Bożej Łaskawej ks. kan. dr Jacek Staszak, dziekan dekanatu janowskiego. To on przekazał cztery połączone pomieszczenia przeznaczone na placówkę, znajdujące się na pierwszym piętrze dawnego klasztoru (wejście od kancelarii parafialnej). Podobnie ze środków parafii janowskiej ufundowano konieczne witryny i inne wyposażenie techniczne nowego Muzeum. Za realizację merytoryczną przedsięwzięcia odpowiadał zespół janowskiego Muzeum Regionalnego pod kierunkiem jego Dyrektor B. Nazarewicz. W toku prac przygotowawczych udało się zgromadzić ogółem kilkadziesiąt różnych zabytków ruchomych - naczyń i innych przedmiotów liturgicznych, rękopisów i starodruków. Pochodzą one z różnych źródeł. Część odnaleziono w budynkach poklasztornych i kościelnych m.in. w starej plebanii, część pochodziła z darów osób prywatnych, jeszcze inne nawet ze zbiorów samego ks. dra J. Staszaka. Należy wspomnieć, że w toku poszukiwań zespół janowskich muzealników odnalazł dotychczas nieznane zabytki, jak malowane na płótnie przedstawienie sceny VI drogi krzyżowej pochodzące z XVII lub XVIII w., oraz księgę zmarłych parafii janowskiej z 1915 r. Całość zinwentaryzowanych i przekazanych na potrzeby powstającej placówki muzealnej zabytków obejmuje okres od 1654 r. po XX w.

W pierwszej ze wspomnianych sal umieszczono wyłącznie naczynia i szaty liturgiczne stanowiące wyposażenie klasztoru i kościoła klasztornego. Liczbowo przeważają tu lichtarze i różnokolorowe ornaty z XVIII-XIX w., pozłacane monstrancje i relikwiarze, m.in. św. Tekli, z XVIII w., a znaleźć tu można także lavabo (lakierowana drewniana podstawa $\mathrm{z}$ metalową misą i zawieszonym cynowym zbiornikiem) do rytualnego obmywania rąk z XIX w. Bliżej należy przyjrzeć się chociaż dwóm ze wspomnianych ornatów. Pierwszy biały z haftowanymi przed- 
stawieniami Marii i św. Izabeli z II poł. XVIII w. oraz kolumną przodu i tyłu z czerwonego aksamitu. Drugim jest złoty ornat uszyty w XVIII w. z tkaniny broszowanej, uzupełnionej po bokach w XIX w. podobną tkaniną broszowaną i lansowaną. Ogólny stan tych ornatów, choć już eksponowanych, to jeszcze przed końcem konserwacji, nie jest najlepszy. Powierzchnia tkanin jest przetarta, metalowe nici wytarte, widoczne są spękania i zacieki, najgorzej jednak zachowały się aplikowane elementy haftu. Ubytki częściowo uzupełnili już pracownicy Muzeum Regionalnego. Najstarszym spośród zgromadzonych w tej sali zabytków jest kielich mszalny datowany na XVII w. Jednak największą wartość artystyczną, historyczną i symboliczną wydają się przedstawiać dominikańska chorągiew procesyjna z 1714 r. oraz „tron papieski” z Sandomierza z 1999 r. Na tą pierwszą zwróciła szczególną uwagę prof. dr hab. Helena Hryszko (Akademia Sztuk Pięknych w Warszawie), rzeczoznawca Ministerstwa Kultury i Dziedzictwa Narodowego w zakresie ochrony zabytków ruchomych, specjalizująca się w konserwacji tkanin, która przed otwarciem Muzeum dokonała przeglądu tamtejszego zbioru wyrobów tekstylnych. Ikonografia chorągwi zawiera niezwykle rzadkie przedstawienie postaci św. Dominika z psem. Warto dodać, że w polskich zbiorach zachowało się jedynie 10 chorągwi kościelnych z XVII-XVIII w., w tym 4. dominikańskie (dwie z klasztoru z Krakowa, po jednej z Lublina i Warszawy). Janowska chorągiew Ojców Dominikanów jest więc dopiero 5. taką zachowaną w kraju. Niestety, zabytek ten zachował się w wyjątkowo złym stanie i wymaga natychmiastowej interwencji konserwatorskiej. Wydaje się, że nieodwracalnym może być całkowite wykruszenie się haftowanych twarzy postaci. Widoczne są także mechaniczne rozdarcie, ubytki dużej części tkaniny, zarejestrowano ponadto obecność szkodliwych mikroorganizmów i degradację włókien jedwabnych. Konserwatorzy mają jednak nadzieję, że chociaż częściowo uda się zrekonstruować malowane partie chorągwi dzięki szczegółowej analizie jej dawnych zdjęć.

W dwóch kolejnych salach umieszczono zabytki piśmiennictwa - rękopisy i starodruki. Górują te pierwsze, spośród których najstarsze stanowią księgi metrykalne prowadzone od $1654 \mathrm{r}$. oraz bardzo interesująca księga klasztornego (dewocyjnego) Bractwa Różańcowego z jej dekretem erekcyjnym zaprowadzona w $1660 \mathrm{r}$. Pierwsza z tych ksiąg uznawana jest przez wielu za najstarszą obecnie zachowaną księgę metrykalna tej serii na Lubelszczyźnie. Jej wartość historyczna jest tym większa, że niezwykle rzadko zdarzają się zachowane księgi metrykalne prowadzone niemal od początku istnienia ośrodka miejskiego, przez co ta eksponowana może stać się istotnym źródłem informacji na temat pierwotnego składu ludności Janowa i jego struktury społecznej. Uzupełnieniem tych informacji może być także wykaz braci i sióstr należących do Bractwa Różańcowego ze wspomnianej księgi erekcyjnej tej konfraterni. Także znaczenie tej księgi jest podobne, jako że jest ona współczesna powstaniu Bractwa. Analogiczne księgi z pobliskich parafii w większości zaginęły, zaś te zachowane są młodsze, jak księgi bractw urzędowskich zachowane od 1748 r., a księgę tamtejszego Bractwa Różańcowego zaprowadzono dopiero w $1801 \mathrm{r}$. Na szczególną uwagę zasługuje jednak zbiór kilkudziesięciunie opracowanych jeszcze, głównierękopiśmiennych, kazańksięży zkościoła w Białej, spośród których najstarsze pochodzą z XVIII w. Zbiór ten cudem 
ocalał z bombardowania kościoła w 1939 r., Muzeum pozyskało go natomiast $z$ rąk prywatnych. Poza tymi znajduje się tam również kilka protokołów wizytacji generalnych parafii Biała od 1806 r., inwentarze parafii bialskiej od 1766 r. oraz akta dekanatu janowskiego z XIX w. Warto wspomnieć, że zespołowi Muzeum Regionalnego udało się odnaleźć i umieścić na ekspozycji także pewne rękopisy, które pochodzą z parafii odległych od Janowa nawet o kilkadziesiąt kilometrów. Są to mianowicie akta parafii Boża Wola, Borów i Potok Wielki z II poł. XIX w., głównie różne protokoły zdawczo-odbiorcze, których droga przedostania się do janowskiego klasztoru i kościoła nie została jak dotychczas odtworzona. Mniejszą część omawianych tu zbiorów stanowią starodruki z XVII-XX w., wśród których wyróżniają się dwa mszały Misale Romanum z 1688 i 1767 r., będące zapewne spuścizną po bibliotece klasztornej. Obok rękopisów i starodruków wystawionych w dwóch omawianych salach ekspozycyjnych znalazły się tam również dwa, służące niegdyś do procesji, feretrony utrzymane w stylu rokokowym, z których starszy datowany jest na ok. 1785 r. Na potrzebę otwieranego Muzeum przygotowano dwie kopie postaci przedstawionych na nich, w skali 1:1, na które następnie zawieszono sukienki pierwotnie znajdujące się na feretronach. Uzupełnieniem całości są przedmioty liturgiczne z XIX-XX w., jak chociażby te służące do udzielania chrztów, ale także zestaw kilkunastu pochodzących z XIX w. pieczęci służących janowskiej kancelarii parafialnej oraz niewielki zbiór fotografii z XIX-XX wieku.

W ostatniej, wciąż jeszcze przygotowywanej na potrzeby Muzeum salce, znajdują się obecnie zabytkowe drzwi prowadzące niegdyś do zakrystii kościoła klasztornego wraz z kamiennym progiem oraz fragment drewnianych odrzwi, $\mathrm{z}$ fragmentarycznie zachowanych napisem JUGITER PARTE AD.

$\mathrm{W}$ toku uroczystego przekazania ekspozycji miejscowej społeczności Dyrektor Muzeum Regionalnego B. Nazarewicz wyraziła słowa żalu, że nie udało się umieścić w salach wystawowych zarchiwizowanej obecnie w Archiwum Kapituły Metropolitalnej w Krakowie księgi cudów z klasztoru janowskiego opisującej 166 lokalnych przypadków cudów i łask z lat 1645-1802. Muzealnicy janowscy, którzy posiadają jej kopię, mają jednak nadzieję, że w niedługim czasie uda się księgę pozyskać dla Muzeum klasztornego w długoterminowy depozyt. Prowadzone przez nich w ostatnim roku prace dowiodły także, iż nie wszystkie janowskie zabytki podominikańskie zostały w latach 1864-1867 wywiezione do klasztoru klimontowskiego. 